\title{
Food of the sea urchins Strongylocentrotus nudus and Hemicentrotus pulcherrimus associated with vertical distributions in fucoid beds and crustose coralline flats in northern Honshu, Japan
}

\author{
Hikaru Endo ${ }^{1, *}$, Nobuyasu Nakabayashi ${ }^{2}$, Yukio Agatsuma ${ }^{1}$, Kazuya Taniguchi ${ }^{1}$ \\ ${ }^{1}$ Laboratory of Marine Plant Ecology, Graduate School of Agricultural Science, Tohoku University, Aoba, Sendai, \\ Miyagi 981-8555, Japan \\ ${ }^{2}$ Akita Prefectural Institute of Fisheries, Oga, Akita 010-0531, Japan
}

\begin{abstract}
The vertical distribution and food of Strongylocentrotus nudus and Hemicentrotus pulcherrimus in fucoid beds at depths of 0.3 to $2.4 \mathrm{~m}$ and coralline flats at depths of 2.4 to $4.7 \mathrm{~m}$ were studied monthly from May 2001 to May 2002 off the Oga Peninsula, Akita prefecture, northern Japan. No seasonal migration of $S$. nudus from coralline flats to the fucoid beds occurred, as sufficient food was available in the form of sessile animals. Crustose corallines were generally predominant in the gut contents of sea urchins in fucoid beds, where their density was extremely low. Hemicentrotus pulcherrimus inhabit both fucoid beds and coralline flats. The main foods required for this sea urchin's gonad production are the dominant algae and sessile animals found in each algal community. The low amounts of fucoids in the gut contents of each species suggest low consumption, possibly because of difficulty in grazing fully grown and erect thalli and feeding deterrents.
\end{abstract}

KEY WORDS: Sea urchin - Strongylocentrotus nudus - Hemicentrotus pulcherrimus · Gut content · Fucoid beds · Gonad development

\section{Resale or republication not permitted without written consent of the publisher}

\section{INTRODUCTION}

Sea urchin roe is consumed mainly in Japan and France. In order to maintain sustainable stocks of commercially harvestable sea urchins, minimum legal sizes, closed areas and seasons, restrictions on harvesting methods and daily catch limits have been imposed, and in Japan transplantation of wild populations and reseeding of hatchery-reared juveniles have been undertaken (Andrew et al. 2002).

In addition, stable algal abundance, which promotes somatic growth and gonad production, is needed to allow sea urchin fisheries to be established and sustained. Hence, there is a need to clarify the vertical distribution and food of sea urchins in relation to algae and invertebrate in fishery areas. This provides basic ecological information on the relation between sea urchins and their foods and also on the impact of fisheries on the environment.
Growth and gonad production of strongylocentrotid species of sea urchins differ with the type of algal beds in which they are found (e.g. Pearse 1980, Meidel \& Scheibling 1998, Agatsuma et al. 2005a,b). The most rapid growth and highest gonad production are found in laminarian beds, followed by algal turf, consisting mainly of red algae such as Chondrus ocellatus. The slowest growth and lowest gonad production are found in coralline flats, where crustose coralline red algae are predominant (Ayling 1981). In algal turf dominated by Dictyotaceae and Laurencia spp., which produce chemicals that deter sea urchin grazing (reviewed by Lawrence et al. 2007), the growth and gonad production of Strongylocentrotus nudus and Hemicentrotus pulcherrimus are lower than in other areas (Agatsuma et al. 2005a, Nakabayashi et al. 2006). These rankings of growth and gonad production in the field have been confirmed by laboratory experiments (Fuji 1967, Keats et al. 1984). 
Foods consumed by strongylocentrotid sea urchins in foliose algal beds and coralline flats have been clarified by gut content analysis of specimens sampled seasonally. The main foods of Strongylocentrotus franciscanus are brown algae in beds of Macrocystis pyrifera, where drift abundance is high, and brown and red algae in coralline flats, where drift abundance is low (Harrold \& Reed 1985). In beds of Laminaria longicruris, the percentages of foliose algae such as Laminaria spp., Chondrus spp., Palmaria spp., and Desmarestia spp. in the gut contents of $S$. droebachiensis are higher than those in coralline flats (Meidel \& Scheibling 1998). In beds of Eisenia bicyclis and coralline flats, the main foods of $S$. nudus are E. bicyclis and fucoids, and crustose corallines, respectively (Sano et al. 2001). The main foods of Hemicentrotus pulcherrimus are Chondrus spp. and Acrosorium polyneurum in algal turf and crustose corallines in coralline flats (Agatsuma et al. 2006). Agatsuma et al. (2005a, 2006) did not quantify the abundance of food (algae and invertebrates) in their studies.

In many parts of the world, large perennial brown algae grow in rocky upper subtidal zones and crustose corallines are predominant in the deeper zones (reviewed by Harrold \& Pearse 1987). The larvae of Strongylocentrotus nudus, S. purpuratus, S. franciscanus, and $S$. droebachiensis settle and metamorphose abundantly on rocky subtidal bottoms overgrown by crustose corallines (Cameron \& Schroeter 1980, Rowley 1989, Sano et al. 1998, Balch \& Scheibling 2000). From July to October, $S$. nudus $>20 \mathrm{~mm}$ diameter (1 yr old) in coralline flats migrate to shallow waters, where they feed on Laminaria religiosa or Eisenia bicyclis and develop gonads (Sano et al. 2001, see review by Agatsuma 2007). From November to March, Hemicentrotus pulcherrimus adults in coralline flats also migrate to algal turf in shallow waters, where their gonads develop (Agatsuma et al. 2006). S. fraciscanus and $S$. droebachiensis also migrate from coralline flats to laminarian beds and form dense feeding aggregations at the margin of these beds (Dean et al. 1984, reviewed by Scheibling \& Hatcher 2007). However, vertical distributions and foods of sea urchins in fucoid beds and subsequent coralline flats have not been studied seasonally.

The aim of the present study was to clarify which food items are required for gonad development of Strongylocentrotus nudus and Hemicentrotus pulcherrimus in fucoid beds and corallines flats in relation to the seasonal vertical distributions of the species.

\section{MATERIALS AND METHODS}

Site characteristics. This study was conducted in shallow rocky subtidal waters off the coast of Tsubaki $\left(39^{\circ} 51^{\prime} \mathrm{N}, 1^{\circ} 49^{\prime} \mathrm{E}\right)$ along the Oga Peninsula. In May
2001, a series of iron plates $(10 \times 10 \mathrm{~cm}, 8 \mathrm{~mm}$ thickness), each welded to an iron staple $(3 \times 8 \mathrm{~cm}, 9 \mathrm{~mm}$ diameter), were stuck to the bottom using epoxy adhesive at intervals of $5 \mathrm{~m}$ from the lowest water level to $60 \mathrm{~m}$ offshore perpendicularly to the coast line. A leaded rope marked at $1 \mathrm{~m}$ intervals was fixed to the iron staple, and a permanent transect $(60 \mathrm{~m}$ long $\times 2 \mathrm{~m}$ wide) with the rope set at its center was designated as the study site. Depth was measured with a waterpressure gauge at intervals of $1 \mathrm{~m}$ along the rope. To clarify whether the bottom consisted of unstable substrate such as cobbles, which is unsuitable for fucoid growth (Taniguchi \& Ohkubo 1975) or as a habitat for Hemicentrotus pulcherrimus (Kawana 1938), the bottom profile at the study site was sketched precisely using a $1 \times 1 \mathrm{~m}$ quadrat in a SCUBA survey.

At the study site, boulders and cobbles were scattered in hollows on flat rock from 0 to $20 \mathrm{~m}$ offshore (0.3 to $1.9 \mathrm{~m}$ depth). Only cobbles were found in hollows from 20 to $30 \mathrm{~m}$ (1.4 to $2.8 \mathrm{~m}$ depth). The substrata consisted mainly of undulating rocks, including boulders and cobbles at 30 to $40 \mathrm{~m}$ (2.1 to $3.6 \mathrm{~m}$ depth), and of boulders and cobbles at 40 to $60 \mathrm{~m} \mathrm{(3.3} \mathrm{to} 4.7 \mathrm{~m}$ depth) (Fig. 1). Algal vegetation was clearly divided into fucoid beds at 0.3 to $2.4 \mathrm{~m}$ depth and coralline flats at 2.4 to $4.7 \mathrm{~m}$ depth. Fucoid beds and coralline flats were each divided into upper and lower zone from the characteristics of substratum. The substrate in the lower fucoid beds was dominated by unstable cobbles, unsuitable for the habitation of Hemicentrotus pulcherrimus (Kawana 1938).

Mean seawater temperatures every $10 \mathrm{~d}$ during the study and for $20 \mathrm{yr}$ from 1981 to 2000 were obtained from the data at Unosaki $\left(39^{\circ} 51^{\prime} \mathrm{N}, 139^{\circ} 48^{\prime} \mathrm{E}\right)$, near the study site, measured by Akita Prefectural Institute of Fisheries.

Sampling of algal assemblages. Monthly collection of marine algae was conducted 1 to $2 \mathrm{~m}$ away from the transect at distances of $0,10,20,30,35,40,50$ and $60 \mathrm{~m}$ offshore using 3 or 4 quadrats $(50 \times 50 \mathrm{~cm})$. The crustose corallines were not sampled. The algae collected were identified, and the wet weight of each species was measured in each quadrat. The algae identified were classified into 4 groups: small annuals, small perennials (ca. $<50 \mathrm{~cm}$ in length), large annuals and large perennials (ca. $>1 \mathrm{~m}$ in maximum length) (Taniguchi 1996).

Density. Densities of Strongylocentrotus nudus and Hemicentrotus pulcherrimus at each of the 4 characterized areas were surveyed monthly by SCUBA using $40,20,20$ and 40 quadrats $(1 \times 1 \mathrm{~m})$, respectively, from May 2001 to May 2002.

Gonad analysis. Specimens ( $\mathrm{n}=17$ to 46 ) of adult Strongylocentrotus nudus ( $>45 \mathrm{~mm}$ in diameter; Fuji 1960) and Hemicentrotus pulcherrimus (>26 $\mathrm{mm}$ in diameter; Kawana 1938) were collected in the fucoid 

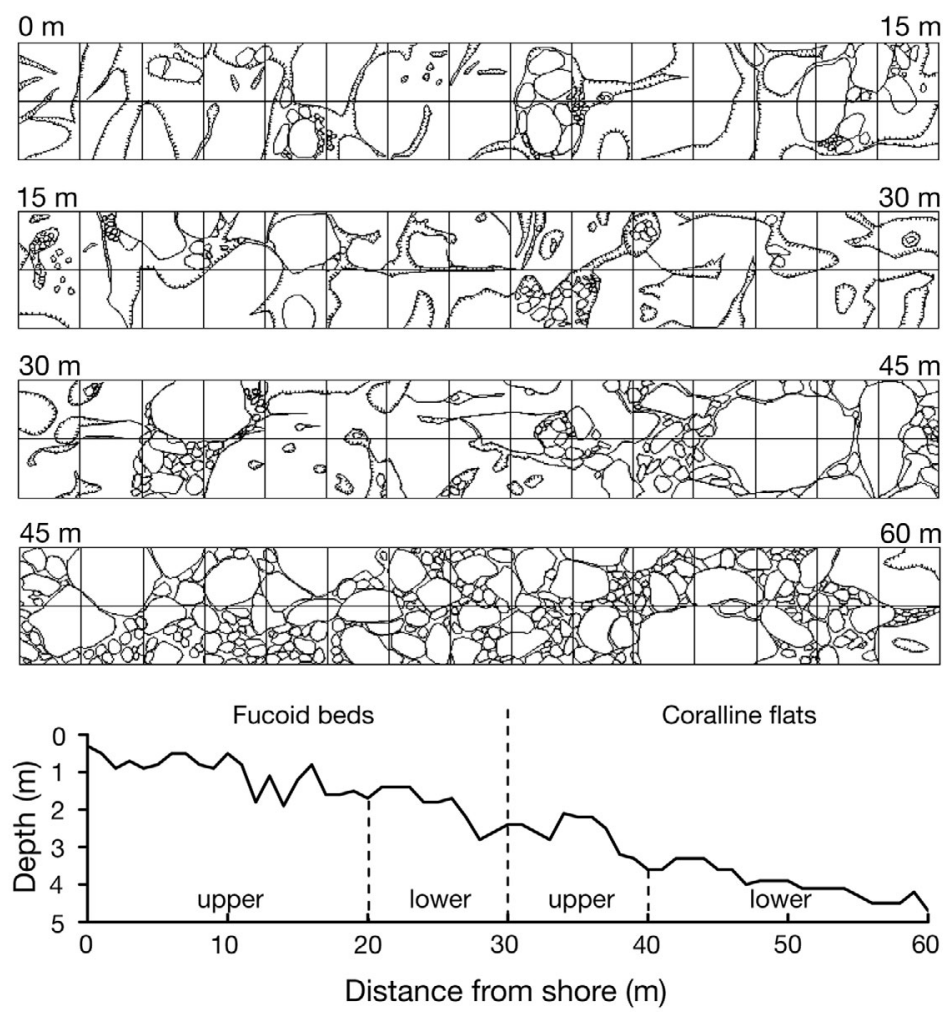

Fig. 1. Bottom profile of permanent transect and depth of the 4 characterized areas at the study site

beds and coralline flats monthly. The horizontal test diameters without spines were measured by a vernier caliper (0.1 $\mathrm{mm}$ accuracy). The body and gonad wet weights were measured using an electrical balance $(0.1 \mathrm{~g}$ accuracy), and the gonad index (gonad wet weight $\times 100 /$ body wet weight) was calculated. Gonad development processes were classified by macroscopic observations into 3 stages: maturation (with gametes oozing from an large gonad), spent (with relict gametes in a shrunken gonad) and immature (without gametes).

Gut contents analysis. Gut contents from 3 of the largest specimens of Strongylocentrotus nudus and Hemicentrotus pulcherrimus collected from the fucoid beds and coralline flats were preserved individually in $5 \%$ neutral formalin. The components were divided into 3 groups: algae, animals and minerals, according to shape, color and hardness, using a stereomicroscope. In addition, algae were classified into family, genus, or species according to specific cell structures using a dissecting microscope according to Segawa (1956) and Yoshida (1998). Each sorted food item was then blotted on filter paper (Whatman GF/C), dried for $12 \mathrm{~h}$ at $80^{\circ} \mathrm{C}$ in a hot-air convection oven, and then weighed using a microbalance (1 mg accuracy). Gut contents index [gut contents weight $\times 10^{4} /$ body weight - gonad weight)] (Sano et al. 2001) was calculated for each food item. Percentage by weight of each food item in the total gut contents of both species each month was subjected to cluster analysis based on Euclidean distances using Ward's method.

Statistical analysis. Significance of differences in the densities of each sea urchin species among months and the 4 characterized areas at the study site was analyzed by Kruskal-Wallis' test and Tukey's multiple comparison test. Significance of differences in gonad indices among months was analyzed using the same statistical tests, and that of differences between the 2 algal communities was analyzed by MannWhitney $U$-test.

\section{RESULTS}

\section{Algal assemblages and seawater temperature}

The standing crops of each algal life form in the fucoid beds and coralline flats are shown in Fig. 2. In the fucoid beds, year-round high standing crops of large perennials were found. The total exceeded $2 \mathrm{~kg} \mathrm{~m}^{-2}$ from August to November in 2001 and March to May in 2002. The large perennial brown algae Myagropsis myagroides, Sargassum piluliferum and S. patens accounted for 80 to $90 \%$ of the total. The standing crops of $M$. myagroides decreased from May 2001 to $<0.3 \mathrm{~kg} \mathrm{~m}^{-2}$ between July and February 2002, then increased until May. Those of $S$. piluliferum increased rapidly from May-July to August-November and decreased temporarily in February, then stagnated around $1 \mathrm{~kg} \mathrm{~m}^{-2}$. Standing crops of $S$. patens increased gradually from May to October and decreased to $<0.5 \mathrm{~kg} \mathrm{~m}^{-2}$ between November and January. They then reached a maximum of $>1 \mathrm{~kg} \mathrm{~m}^{-2}$ in February and March, and decreased until May. Among small perennial algae, articulated corallines accounted for 91 to $100 \%$ of the total. Their standing crops ranged from 0.3 to $0.5 \mathrm{~kg} \mathrm{~m}^{-2}$ from May to July 2001 , and thereafter stagnated at $<0.2 \mathrm{~kg} \mathrm{~m}^{-2}$. The small annual algae were mainly the red alga Polysiphonia spp. and the brown alga Punctaria latifolia, which had high standing crops of 0.3 to $0.5 \mathrm{~kg} \mathrm{~m}^{-2}$ between March and May. In coralline flats, year-round standing crops of large perennials and annuals and small perennials were $<80 \mathrm{~g} \mathrm{~m}^{-2}$, markedly less than those in the fucoid beds. Those of small annuals increased temporarily between March and May, when Polysiphonia spp. colonized.

Seawater temperature during this study reached a peak of $26.2^{\circ} \mathrm{C}$ in late August and a minimum of $7.1^{\circ} \mathrm{C}$ in February 2002, similar to the averages over a $20 \mathrm{yr}$ period (Fig. 3). 


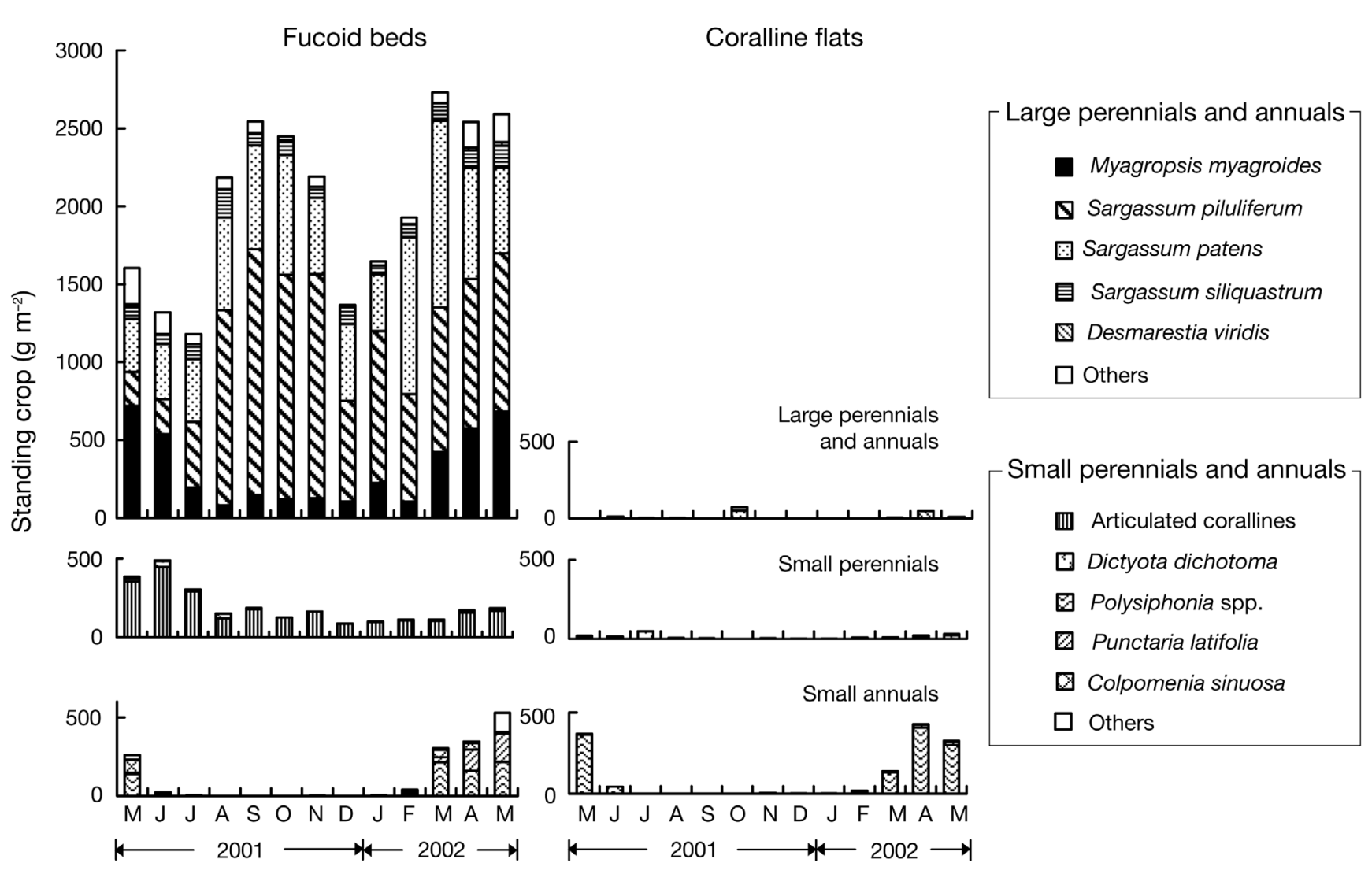

Fig. 2. Seasonal changes in standing crops by group in fucoid beds and coralline flats (excluding crustose corallines)

\section{Vertical distribution}

Seasonal changes in the densities of Strongylocentrotus nudus and Hemicentrotus pulcherrimus in the 4 characterized areas at the study site are shown in Fig. 4. Densities of $S$. nudus in the upper and lower fucoid beds were markedly low, 0 to 0.1 ind. $\mathrm{m}^{-2}$. By contrast, there were 0.1 to 1.0 and 0.8 to 2.9 ind. $\mathrm{m}^{-2}$ in the upper and lower coralline flats, respectively. Significant differences in densities among the 4 areas at the study site were found throughout the year $\left(\chi^{2}=\right.$ 38.177 to $81.238, \mathrm{df}=3, \mathrm{p}<0.0001$ ). The densities in the lower coralline flats were significantly higher than those in the other 3 areas $(p<0.05)$. There were significant differences in the densities among months (upper coralline flats: $\chi^{2}=26.450, \mathrm{df}=12, \mathrm{p}=0.009$; lower coralline flats: $\chi^{2}=54.536, \mathrm{df}=12, \mathrm{p}<0.0001$ ). In particular, the densities in May 2001 in the upper and lower coralline flats were significantly higher than those in the other months $(\mathrm{p}<0.05)$.

Densities of Hemicentrotus pulcherrimus were 0.9 to 2.6 ind. $\mathrm{m}^{-2}$ in the upper fucoid beds and 0.1 to 0.7 ind. $\mathrm{m}^{-2}$ in the lower fucoid beds, and 0.4 to 2.0 ind. $\mathrm{m}^{-2}$ in the upper coralline flats and 0.5 to 1.3 ind. $\mathrm{m}^{-2}$ in the lower coralline flats. There were significant differences in the densities among months in the upper fucoid beds $\left(\chi^{2}=26.897, \mathrm{df}=12, \mathrm{p}=0.008\right)$ and in the lower coralline flats $\left(\chi^{2}=39.833, \mathrm{df}=12, \mathrm{p}<0.0001\right)$, while no significant differences were found by post hoc test. No significant differences in densities among months were found in the lower fucoid beds $\left(\chi^{2}=\right.$ $19.153, \mathrm{df}=12, \mathrm{p}=0.085$ ) or in the upper coralline flats $\left(\chi^{2}=11.655, \mathrm{df}=12, \mathrm{p}=0.474\right)$. Significant differences among areas were found, except from July to December $2001\left(\chi^{2}=8.205\right.$ to 21.930 , df $\left.=3, p<0.05\right)$. The densities in the lower fucoid beds were significantly lower than those in the upper fucoid beds (in June 2001, January and April 2002) and lower coralline flats (in February and May 2002) $(\mathrm{p}<0.05)$.

\section{Gonad changes}

Mean $( \pm \mathrm{SD})$ test diameters of Strongylocentrotus nudus and Hemicentrotus pulcherrimus were $52.1 \pm$ 4.49 and $29.3 \pm 2.77 \mathrm{~mm}$, respectively. Seasonal changes in the gonad developmental stages and gonad indices of each species are shown in Figs. $5 \& 6$. 
Gonads of $S$. nudus in each algal community were at the mature stage in August or September and in the spent stage in September and October. Mature H. pulcherrimus individuals occurred in November or December, and the spent stage occurred from March to May in both algal communities. There were significant differences in the gonad indices of $S$. nudus among months in the fucoid beds $\left(\chi^{2}=66.050\right.$, df $=12$, $\mathrm{p}<$ $0.0001)$ and coralline flats $\left(\chi^{2}=194.008\right.$, df $=12, \mathrm{p}<$ $0.0001)$. The gonad index of $S$. nudus reached a peak of 17.3 in July 2001, when gonads were immature. The index decreased significantly from August to November $(\mathrm{p}<0.05)$, when gonads were in the mature and spent stages. The index increased significantly until May ( $p<0.05)$. In the coralline flats, the gonad index reached a peak of 13.7 in July 2001 and decreased significantly from September to November $(p<0.05)$. It

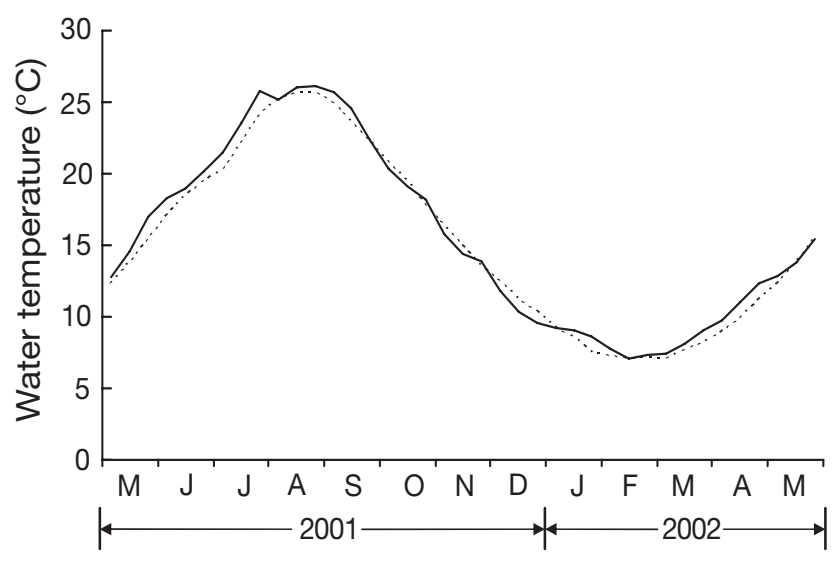

Fig. 3. Seawater surface temperature during the present study (solid line) and the averages for $20 \mathrm{yr}$, from 1981 to 2000 (dotted line)
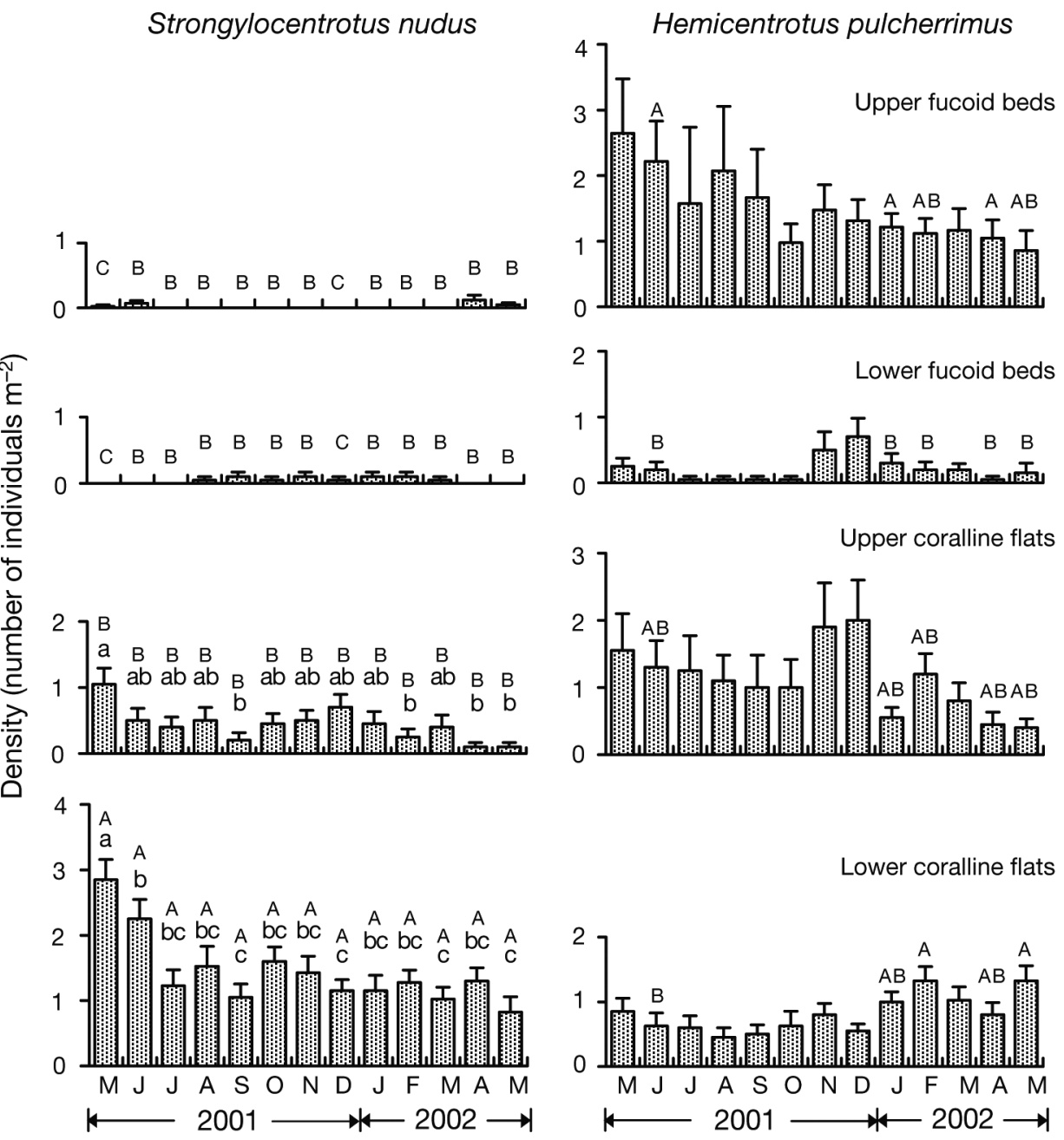

Lower coralline flats

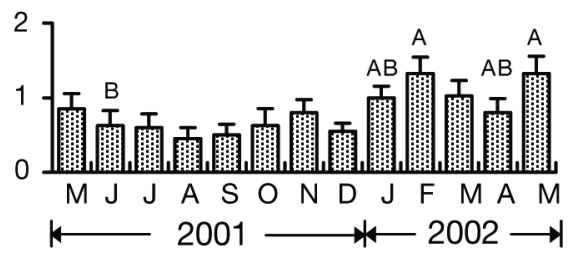

Fig. 4. Strongylocentrotus nudus and Hemicentrotus pulcherrimus. Seasonal changes in densities (mean $+\mathrm{SE})$ at the 4 areas, upper and lower fucoid beds and upper and lower coralline flats, at the study site. Lower case letters represent significant differences among months; upper case letters represent significant differences among the 4 areas at the study site 
Strongylocentrotus nudus Hemicentrotus pulcherrimus Fucoid beds

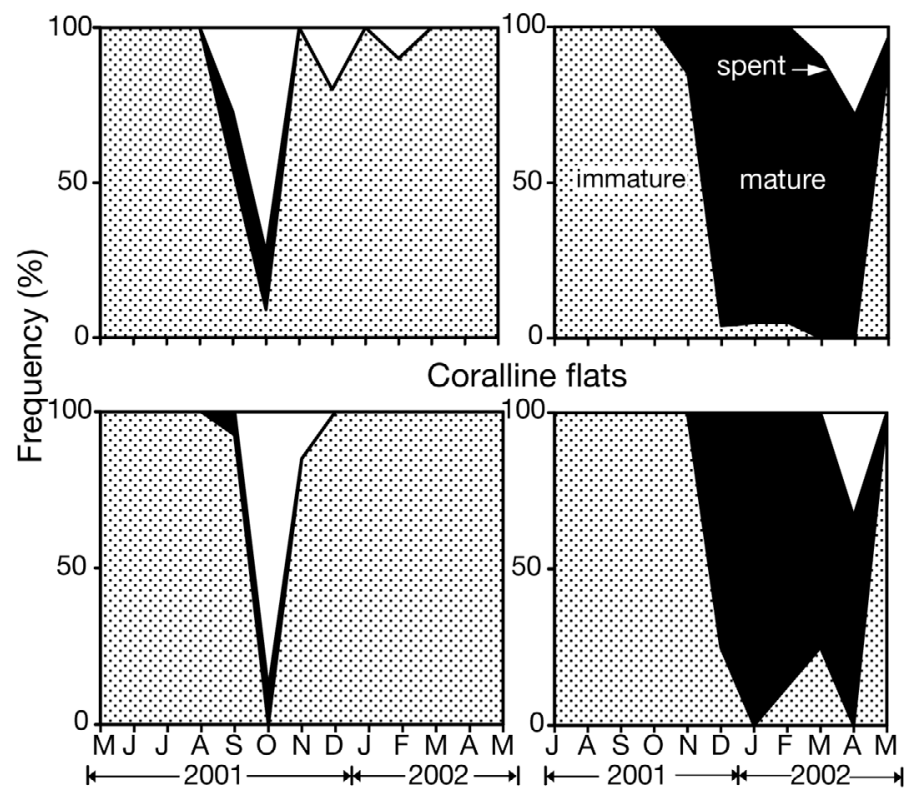

Fig. 5. Strongylocentrotus nudus and Hemicentrotus pulcherrimus. Seasonal changes in the gonad developmental stages at fucoid beds and coralline flats

increased significantly until May ( $\mathrm{p}<0.05)$. There were significant differences in the gonad indices in both algal communities in July, August, October, November, January and May 2002 ( $\mathrm{p}<0.05$ ). Gonad indices of $H$. pulcherrimus were low, 6.3 to 9.8 in fucoid beds and 4.6 to 10.5 in coralline flats, while there were significant differences in gonad indices among months in the fucoid beds $\left(\chi^{2}=39.785\right.$, df $\left.=12, \mathrm{p}<0.0001\right)$ and coralline flats $\left(\chi^{2}=57.544\right.$, df $=12, \mathrm{p}<$ 0.0001). In each community, the indices in May 2002 were significantly higher than those in other months $(\mathrm{p}<0.05)$. No significant differences in the index between the communities were evident all year round $(p>$ 0.05).

\section{Gut contents}

Taxa of food items found in the gut contents of each sea urchin species and the algae collected around the study site are shown in Table 1. The algae collected contained 32 species of small annuals, 13 species of small perennials, 3 species of large annuals and 6 species of large perennials. Among these algal species, 87 and $85 \%$ were found in the gut contents of
Strongylocentrotus nudus and Hemicentrotus pulcherrimus, respectively. Epibenthic animals (Porifera, Cnidaria, Annelida, Mollusca and Arthropoda), wings of terrestrial insects, fragments of terrestrial plants and sand were also found.

Seasonal changes in the gut contents indices of the 6 main components (fucoid algae, crustose corallines, articulate corallines, small algae, animals and others) are shown in Fig. 7. In the fucoid beds, the gut contents indices of Strongylocentrotus nudus fell from May to July and reached a minimum in September, then rose rapidly to a maximum in November. Thereafter, the indices fell gradually until February, rapidly in March, and then rose until May. The main foods were algae, although crustose corallines were predominant, except in May, July, January and February, when the gut contents indices of fucoids showed a relative increase. Sessile animals such as Polychaeta with tubes and Cirripedia were also found. In the coralline flats, the indices fell from May to a minimum in August and rose rapidly to a maximum in November. Thereafter, the indices fell gradually until February and rose again in May. The main foods were crustose corallines and sessile animals.

In fucoid beds, the gut contents indices of Hemicentrotus pulcherrimus fell from May to July and reached a minimum in September. The indices rose in October and fell in November, then rose rapidly and reached a maximum in January. Thereafter, the indices fell gradually until March and rose again in April, then fell

8

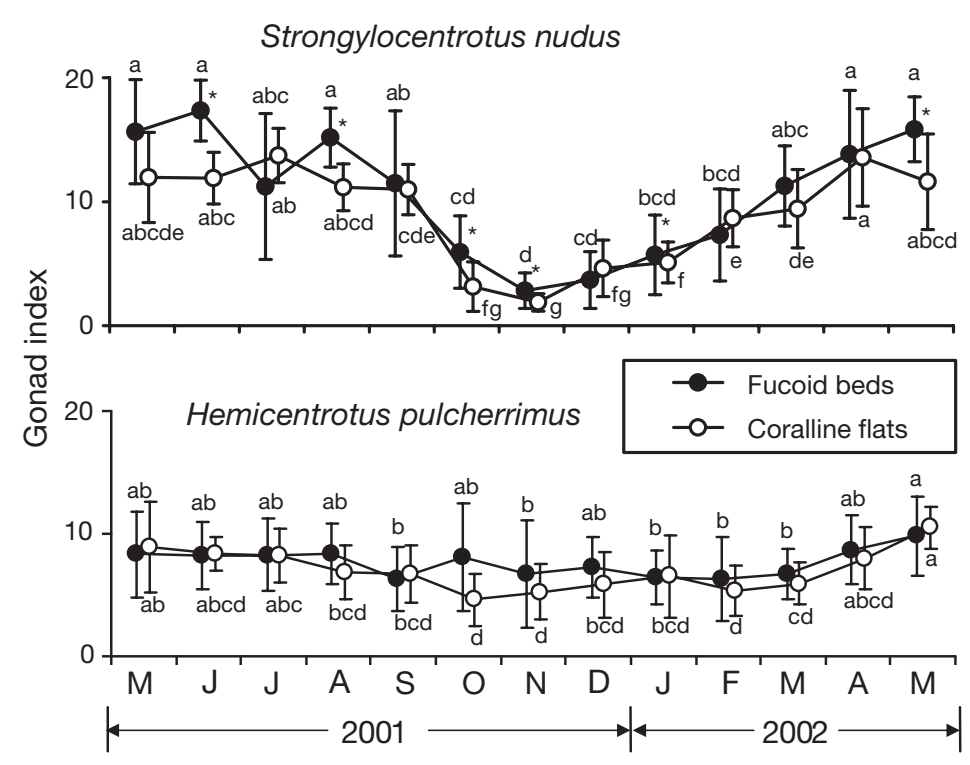

Fig. 6. Strongylocentrotus nudus and Hemicentrotus pulcherrimus. Seasonal changes in the gonad indices (mean \pm SD) for fucoid beds and coralline flats. Lower case letters represent significant differences among months; asterisks represent significant differences between the 2 algal communities 
Table 1. Gut contents of Strongylocentrotus nudus $(\bullet)$, Hemicentrotus pulcherrimus (O) and marine algae ( $\square$ ) collected in fucoid beds and coralline flats. FB: fucoid beds; CF: coralline flats; ND: no data

\begin{tabular}{|c|c|c|c|c|c|}
\hline & FB & $\mathrm{CF}$ & & FB & $\mathrm{CF}$ \\
\hline Small annuals & & & D. prolifera (Okamura) Okamura & $\square$ & \\
\hline Enteromorpha undetermined & - $\bigcirc \square$ & - $\bigcirc \square$ & D. undulate Holmes & $\square$ & \\
\hline Ulva pertusa Kjellman & - ० व & - ० & Dictyota dichotoma (Hudson) & - $\bigcirc \square$ & - $\bigcirc \square$ \\
\hline Chaetomorpha undetermined & & - $\bigcirc$ 口 & Lamouroux & & \\
\hline Cladophora undetermined & - $\bigcirc \square$ & - $\bigcirc \square$ & Distromium decumbens (Okamura) & - & \\
\hline Ectocarpales undetermined & & 0 & Levring & & \\
\hline Sphacelaria undetermined & - 0 & - 0 & Pachydictyon coriaceum (Holmes) & $\square$ & \\
\hline $\begin{array}{l}\text { Leathesia difformis (Linnaeus) } \\
\text { Areschoug }\end{array}$ & $\square$ & & $\begin{array}{l}\text { Okamura } \\
\text { Articulated corallines }\end{array}$ & - 0 & - 0 \\
\hline Punctaria latifolia Greville & - $\bigcirc \square$ & - $\bigcirc \square$ & Marginisporum undetermined & $\square$ & $\square$ \\
\hline $\begin{array}{l}\text { Colpomenia sinuosa } \\
\text { (Mertens ex Roth) Derbès et Solier }\end{array}$ & - ○ & - $\bigcirc \square$ & $\begin{array}{l}\text { Jania undetermined } \\
\text { Gelidium pusillum (Stackhouse) }\end{array}$ & ○ & $\circ \circ$ \\
\hline Petalonia fascia (O. F. Müller) Kuntze & - 0 & 0 & Le Jolis & & 更 \\
\hline Scytosiphon lomentaria (Lyngbye) Link & - 0 & $\bullet \circ$ & Gelidium undetermined & - ○ & - $\bigcirc \square$ \\
\hline Porphyra undetermined & - 0 & $\bullet \circ \square$ & Chondracanthus intermedius & - ○ & $\bullet \circ \square$ \\
\hline Acrochaetiales spp. & $\bullet$ & - 0 & (Suringar) Hommersand & & \\
\hline Bonnemaisonia hamifera Hariot & $\square$ & $\square$ & Ahnfeltiopsis flabelliformis (Harvey) & - & - \\
\hline $\begin{array}{l}\text { Gloeophycus koreanum I. K. Lee et } \\
\text { S. A. Yoo }\end{array}$ & & & $\begin{array}{l}\text { Masuda } \\
\text { Plocamium telfairiae (Hooker et Harvey) }\end{array}$ & & \\
\hline Grateloupia imbricata Holmes & $\square$ & & Harvey & & \\
\hline Grateloupia undetermined & & $\square$ & Gracilaria textorii (Suringar) Hariot & O 口 & - $\bigcirc \square$ \\
\hline Hypnea undetermined & - 0 & - 0 & Champia parvula (C. Agardh) Harvey & - 0 & - 0 \\
\hline Callophyllis undetermined & - $\bigcirc \square$ & - $\bigcirc \square$ & Laurencia intermedia Yamada & 0 & \\
\hline $\begin{array}{l}\text { Portieria hornemannii (Lyngbye) Silva } \\
\text { Schizymenia dubvi (Chauvin) J. Agardh }\end{array}$ & - $\square$ & & L. okamurae Yamada & $\bullet \circ \square$ & - $\bigcirc \square$ \\
\hline Aglaothamnion callophyllidicola & & & $\begin{array}{l}\text { L. pinnata Yamada } \\
\text { Large annuals and perennials }\end{array}$ & 000 & \\
\hline $\begin{array}{l}\text { (Yamada) Boo, Lee, Rueness et Yoshida } \\
\text { Antithamnion nipponicum Yamada } \\
\text { et Inagaki }\end{array}$ & 0 & & $\begin{array}{l}\text { Desmarestia viridis (Müller) Lamouroux } \\
\text { Ecklonia stolonifera Okamura } \\
\text { Fucales spp. }\end{array}$ & $\begin{array}{l}\bullet \circ \square \\
\bullet \circ \\
\bullet\end{array}$ & $\bullet \circ \square$ \\
\hline $\begin{array}{l}\text { Campylaephora hypnaeoides J. Agardh } \\
\text { Centroceras clavulatum (C. Agardh) }\end{array}$ & $\begin{array}{l}\bullet \\
\bullet\end{array}$ & $\bullet$ & $\begin{array}{l}\text { Mycales spp. } \\
\text { (Meropsis myagroides ex Turner) Fensholt }\end{array}$ & ( & \\
\hline Montagne & & & Sargassum fulvellum (Turner) C. Agardh & 口 & 口 \\
\hline Ceramium spp. & - 0 & - 0 & S. hemiphyllum (Turner) C. Agardh & 口 & 口 \\
\hline C. boydenii Gepp & $\square$ & & S. horneri (Turner) C. Agardh & $\square$ & \\
\hline C. japonicum Okamura & $\square$ & $\square$ & S. micracanthum (Kützing) Endlicher & ㅁ & \\
\hline C. kondoi Yendo & & $\square$ & S. patens C. Agardh & $\square$ & 口 \\
\hline Griffithsia japonica Okamura & • $\bigcirc \square$ & & S. piluliferum (Turner) C. Agardh & $\square$ & 口 \\
\hline Heterosiphonia japonica Yendo & & & S. siliquastrum & $\square$ & $\square$ \\
\hline & O & & (Mertens ex Turner) C. Agardh & & \\
\hline $\begin{array}{l}\text { Erythroglossum minimum Okamura } \\
\text { Acrosorium spp. }\end{array}$ & $\bullet 0^{\square}$ & $\bullet \circ^{\square}$ & Crustaceous algae & & \\
\hline A. polyneurum Okamura & & & Crustose corallines & - OND & - OND \\
\hline A. venulosum (Zonardini) Kylin & & & Peyssonnelia spp. & - OND & - OND \\
\hline A. yendoi Yamada & & & Other plants & & \\
\hline Sorella repens (Okamura) Hollenberg & & - $\bigcirc \square$ & Diatomophyceae & - OND & - OND \\
\hline Chondria undetermined & - $\bigcirc \square$ & - $\bigcirc \square$ & Zosteraceae & OND & OND \\
\hline Herposiphonia subdisticha Okamura & - 0 & 0 & Terrestrial plants & - OND & OND \\
\hline $\begin{array}{l}\text { Leveillea jungermannioides } \\
\text { (Hering et Martens) Harvey }\end{array}$ & 0 & • & Animals & & \\
\hline Neorhodomela undetermined & & & & & \\
\hline Polysiphonia spp. & 0 & - 0 & Hydrozoa & - OND & - OND \\
\hline P. japonica Harvey & $\square$ & & Bryozoa & - OND & - OND \\
\hline P. morrowii Harvey & & & & - OND & - OND \\
\hline sa Harvey & & $\square$ & Gastropoda & - OND & - OND \\
\hline & & & Bivalvia & - OND & - OND \\
\hline Symphyocladia marchantioides (Harvey) & - ○ & - ○ & Cirripedia & - OND & - OND \\
\hline Falkenberg in Engler et Prantl & & & Malacostraca & - OND & - OND \\
\hline S. pennata Okamura & - ○ & - ○ & Terrestrial insect & - ND & ND \\
\hline Small perennials & & & Others & & \\
\hline Caulerpa okamurae Weber-van Bosse & & & $\begin{array}{l}\text { Sand } \\
\text { Unclassified organisms }\end{array}$ & $\bullet O N D$ & - OND \\
\hline Dictyopteris spp. & - 0 & - 0 & Unclassified organisms & - OND & - OND \\
\hline
\end{tabular}


again in May. The main components of the gut contents were fucoid algae and articulated corallines. In coralline flats, the indices rose from May to June and fell in July, reached a minimum in September, and then rose until January. The indices fell in February and rose again to a maximum in April, then fell in May. The main foods were crustose corallines, small algae and sessile animals.

Gut contents compositions clustered from dendrograms of Strongylocentrotus nudus and Hemicentrotus pulcherrimus in fucoid beds and coralline flats are shown in Fig. 8. The gut contents compositions of $S$. nudus were divided into 3 clusters: (1) predominance of crustose corallines, (2) high percentage of animals next to crustose corallines and (3) high percentage of fucoid algae next to crustose corallines. Clusters 1 and 2 were found in coralline flats. Cluster 3 was found mainly in fucoid beds. However, the compositions of fucoid beds in July and November 2001 and from March to May 2002 were included in Cluster 1. The compositions of $H$. pulcherrimus gut contents were divided into 3 clusters: (1) a high percentage of crustose corallines and animals, (2) small algae and (3) fucoid algae and articulated corallines. Clusters 1 and 2 were found mainly in coralline flats. Cluster 3 was found mainly in fucoid beds. The composition of fucoid beds in June 2001 was included in Cluster 1.

\section{DISCUSSION}

The larvae of Strongylocentrotus nudus settle and metamorphose abundantly on rocky subtidal bottoms overgrown by crustose corallines (Sano et al. 1998). $S$. nudus individuals $>1 \mathrm{yr}$ old have been reported to migrate from coralline flats to Laminaria religiosa (see review by Agatsuma 2007) or Eisenia bicyclis beds (Sano et al. 2001), where gonads develop, from July to October and to return to coralline flats between November and March. In contrast, the densities of $S$. nudus in the present study were high in the lower coralline flats and low throughout the year in fucoid beds, suggesting no migration.

In coastal waters of California, high abundance of drift algae as food appears to be an important factor in hindering the migration of Strongylocentrotus fraciscanus and $S$. purpuratus from coralline flats to beds of Macrocystis pyrifera (e.g. Harrold \& Reed 1985). At this study site, fucoids are not the main food items of $S$. nudus in coralline flats or in fucoid beds. High percentages of fucoids in the gut contents were found only in 4 months of the year in fucoid beds. The main food items in coralline flats were crustose corallines and sessile animals, such as Polychaeta with tubes and Cirripedia, similar to those in fucoid beds.

The seasonal maximum gonad index of Strongylocentrotus nudus was 17.3 in fucoid beds, markedly lower
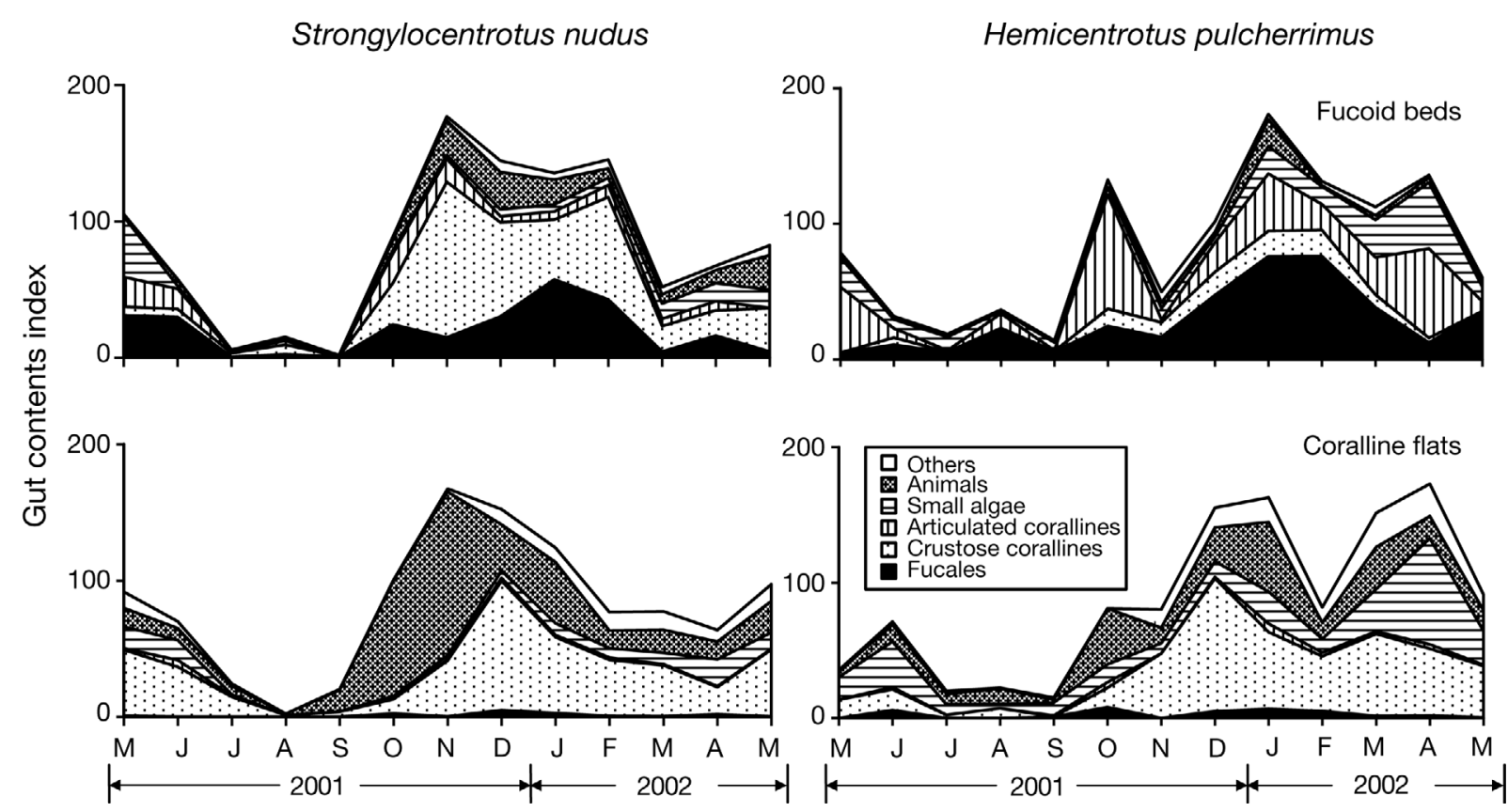

Fig. 7. Strongylocentrotus nudus and Hemicentrotus pulcherrimus. Seasonal changes in the gut contents indices for fucoid beds and coralline flats 
than the value of 25 to 30 in beds of Laminaria japonica and Eisenia bicyclis (Sano et al. 2001, Agatsuma et al. 2005b, see review by Agatsuma 2007). The seasonal maximum gonad index of 13.7 in coralline flats was lower than that in fucoid beds, but higher than 8.5 in the same communities (Agatsuma et al. 2005b). The gonad development in coralline flats is considered to be attributable to consumption of sessile animals, because crus- tose corallines support little or no gonad production (e.g. Keats et al. 1984). The reproductive cycle of $S$. nudus coincides with those at other localities where spawning occurs during September and October (see review by Agatsuma 2007).

From these results, it is concluded that foods such as sessile animals ensure the gonad development of Strongylocentrotus nudus in coralline flats, eliminating
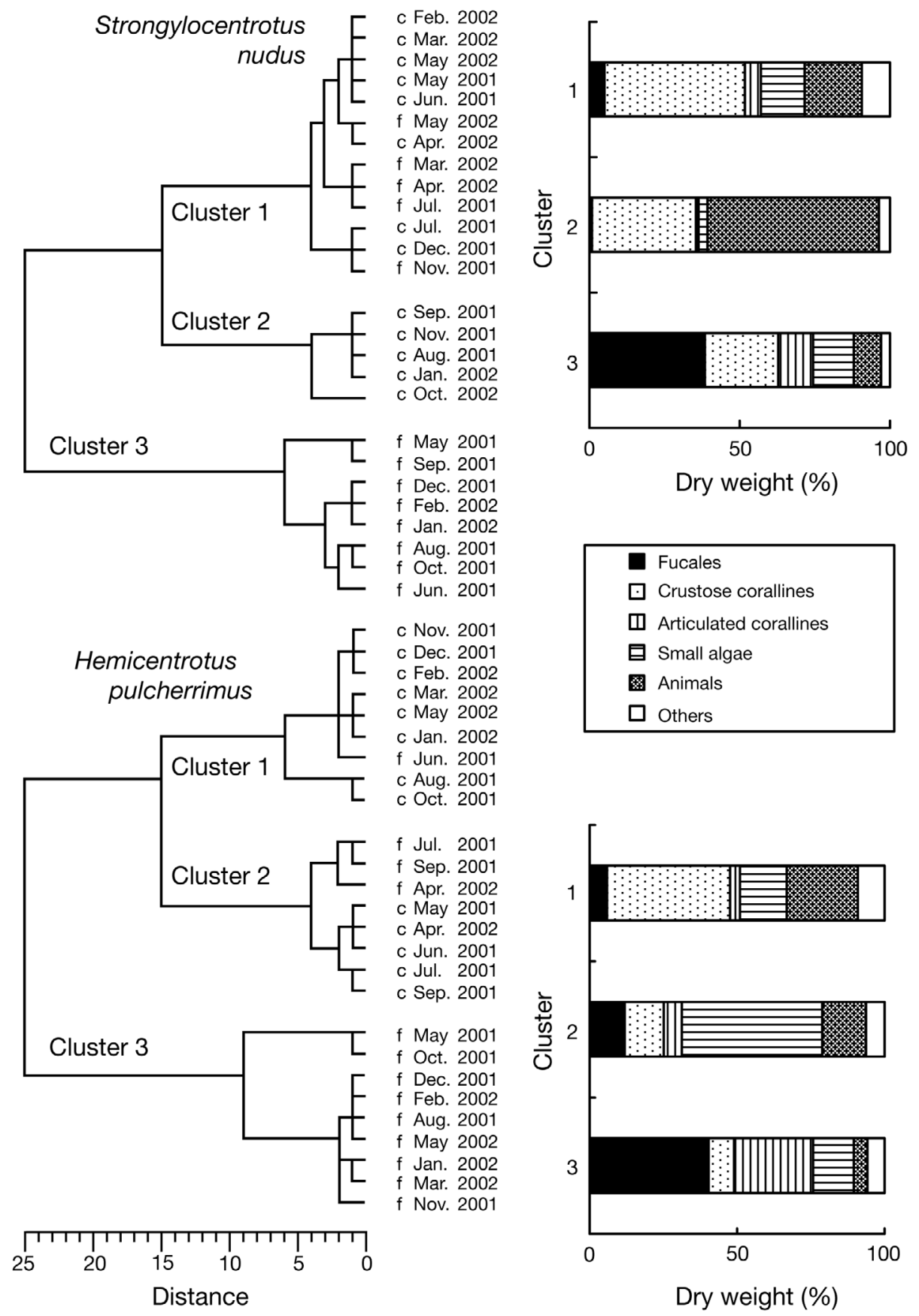

\begin{tabular}{l}
\hline Fucales \\
$\square$ Crustose corallines \\
$\square$ Articulated corallines \\
日 Small algae \\
解 Animals \\
$\square$ Others
\end{tabular}

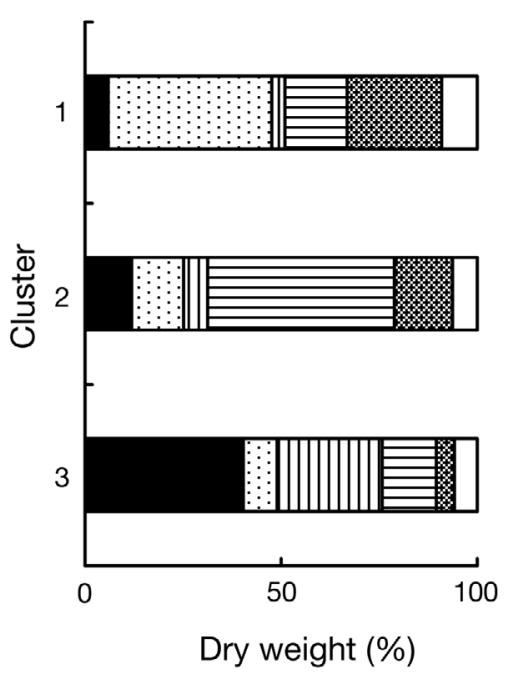

Fig. 8. Strongylocentrotus nudus and Hemicentrotus pulcherrimus. Gut contents compositions at fucoid beds (f) and coralline flats (c) clustered from the dendrograms 
the migration of the sea urchin to foliose algal beds in shallow waters.

Hemicentrotus pulcherrimus inhabit both fucoid beds and coralline flats throughout the year, except the lower fucoid beds where unstable cobbles, unsuitable for their habitation (Kawana 1938), are dominant. Their main food items were crustose corallines, small algae and sessile animals in coralline flats and fucoids and articulated corallines in fucoid beds. However, there were no significant differences in gonad indices or gonad developmental processes between the 2 communities. Seasonal maximum gonad indices in both communities were 11, markedly lower than those in fucoid beds at other localities (Agatsuma \& Nakata 2004, Agatsuma et al. 2005a). This suggests that $H$. pulcherrimus ingest the dominant foods that best support gonad production.

Off the exposed coast of the Mediterranean, Arbacia lixula is predominant at upper depths and Paracentrotus lividus at lower depths (reviewed by Boudouresque $\&$ Verlaque 2007). Similar vertical distribution of 2 sea urchin species was found in the present study. As Hemicentrotus pulcherrimus adults migrate from coralline flats to algal turf in shallower waters where gonad development occurs (Agatsuma et al. 2006), it is concluded that the larvae settle and metamorphose abundantly in coralline flats. $H$. pulcherrimus in the present study site might also migrate to fucoid beds, although some individuals remain in the coralline flats.

At the study site, the fucoid beds contained 8 species of Fucales, among which Myagropsis myagroides, Sargassum piluliferum and $S$. patens were dominant. Most species of Fucales in the Sea of Japan produce their main branches in July and grow to approximately $1 \mathrm{~m}$ in length by October, reaching a maximum development with formation of receptacles in May just prior to their decay (e.g. Taniguchi \& Yamada 1978). These annual cycles of Fucales are not reflected in the gut contents of either sea urchin species. The low amounts of Fucales in the gut contents suggest a low consumption probability, because of difficulty in grazing fully grown and erect thalli. These sea urchins may ingest early-stage thalli, or thalli that have become detached due to strong wave action or decay by chance. Production of the feeding deterrent substance phlorotannin by Fucales, which protects against herbivory (reviewed by Lawrence et al. 2007), and also their hard thallus (Littler et al. 1983) may reduce the extent of grazing by sea urchins.

These results suggest that Strongylocentrotus nudus and Hemicentrotus pulcherrimus do not destroy fucoid beds by their grazing. Gonad size of $H$. pulcherrimus would be influenced by the abundance of their drift algae. Hence, more detailed studies on interaction between sea urchins and fucoid beds are necessary.
Acknowledgements. This paper has been significantly enriched by the comments of Dr. John M. Lawrence, University of South Florida. We sincerely thank former director-generals K. Akama, J. Kato and I. Sasaki of Akita Prefectural Institute of Fisheries for their support during this study. We are also grateful to former director-general Y. Sato of Funakawa Harbor Fisheries Cooperative Association and director-general M. Sato of the Akita Fisheries Cooperative Association for cooperation in the field survey. This study was partially supported by the National Coastal Fisheries Development Association.

\section{LITERATURE CITED}

Agatsuma Y (2007) Ecology of Strongylocentrotus nudus. In: Lawrence JM (ed) Edible sea urchins: biology and ecology, 2nd edn. Elsevier Science Press, Amsterdam, p 443-457

Agatsuma Y, Nakata A (2004) Age determination, reproduction and growth of the sea urchin Hemicentrotus pulcherrimus in Oshoro Bay, Hokkaido, Japan. J Mar Biol Assoc UK 84:401-405

Agatsuma Y, Nakabayashi N, Miura N, Taniguchi K (2005a) Growth and gonad production of the sea urchin Hemicentrotus pulcherrimus in the fucoid bed and algal turf in northern Japan. PSZN I: Mar Ecol 26:100-109

Agatsuma Y, Sato M, Taniguchi K (2005b) Factors causing brown-colored gonads of the sea urchin Strongylocentrotus nudus in northern Honshu, Japan. Aquaculture 249: $449-458$

Agatsuma Y, Yamada H, Taniguchi K (2006) Distribution of the sea urchin Hemicentrotus pulcherrimus along a shallow bathymetric gradient in Onagawa Bay in northern Honshu, Japan. J Shellfish Res 25:1027-1036

Andrew NL, Agatsuma Y, Ballesteros E, Bazhin AG and 24 others (2002) Status and management of the world sea urchin fisheries. Oceanogr Mar Biol Annu Rev 40:343-425

Ayling AM (1981) The role of biological disturbance in temperate subtidal encrusting communities. Ecology 62: 830-847

Balch T, Scheibling RE (2000) Temporal and spatial variability in settlement and recruitment of echinoderms in kelp beds and barrens in Nova Scotia. Mar Ecol Prog Ser 205: 139-154

Boudouresque CF, Verlaque M (2007) Ecology of Paracentrotus lividus. In: Lawrence JM (ed) Edible sea urchins: biology and ecology, 2nd edn. Elsevier Science Press, Amsterdam, p 243-285

Cameron RA, Schroeter SC (1980) Sea urchin recruitment: effect of substrate selection on juvenile distribution. Mar Ecol Prog Ser 2:243-247

Dean TA, Schroeter SC, Dixon JD (1984) Effects of grazing by two species of sea urchins (Strongylocentrotus franciscanus and Lytechinus anamesus) on recruitment and survival of two species of kelp (Macrocystis pyrifera and Pterygophora californica). Mar Biol 78:301-313

Fuji A (1960) Studies on the biology of the sea urchin. II. Size at first maturity and sexuality of two sea urchins, Strongylocentrotus nudus and $S$. intermedius. Bull Fac Fish Hokkaido Univ 11:43-48

Fuji A (1967) Ecological studies on the growth and food consumption of Japanese common littoral sea urchin, Strongylocentrotus intermedius (A. Agassiz). Mem Fac Fish Hokkaido Univ 15:83-160

Harrold C, Pearse JS (1987) The ecological role of echinoderms in kelp forests. In: Jangoux M, Lawrence JM (eds) Echinoderm studies, Vol 2. AA Balkema, Rotterdam, 
p $137-233$

Harrold C, Reed DC (1985) Food availability, sea urchin grazing, and kelp forest community. Ecology 66:1160-1169

Kawana T (1938) Propagation of Hemicentrotus pulcherrimus. Suisan Kenkyushi 33:104-116 (in Japanese)

Keats DW, Steele DH, South GR (1984) Depth-dependent reproductive output of the green sea urchin, Strongylocentrotus droebachiensis (O. F. Müller), in relation to the nature and availability of food. J Exp Mar Biol Ecol 80: $77-91$

Lawrence JM, Lawrence AL, Watts SA (2007) Feeding, digestion, and digestibility. In: Lawrence JM (ed) Edible sea urchins: biology and ecology, 2nd edn. Elsevier Science Press, Amsterdam, p 135-158

Littler MM, Taylor PR, Littler DS (1983) Algal resistance to herbivory on a Caribbean barrier reef. Coral Reefs 2: 111-118

Meidel SK, Scheibling RE (1998) Annual reproductive cycle of the green sea urchin, Strongylocentrotus droebachiensis, in differing habitats in Nova Scotia, Canada. Mar Biol 131: $461-478$

Nakabayashi N, Miura N, Agatsuma Y, Taniguchi K (2006) Growth and gonad production of the sea urchin Strongylocentrotus nudus in relation to marine algal communities along the Japan Sea coast of Akita Prefecture, northwestern Japan. Aquaculture Sci (Jpn J Aquac) 54:365-374 (in Japanese with English abstract)

Pearse JS (1980) Synchronization of gametogenesis in the sea urchins Strongylocentrotus purpuratus and $S$. franciscanus. In: Clark WH, Adams TS (eds) Advances in invertebrate reproduction. Elsevier North Holland, New York, p 53-68

Rowley RJ (1989) Settlement and recruitment of sea urchins (Strongylocentrotus spp.) in a sea-urchin barren ground

Editorial responsibility: John Lawrence (Contributing Editor), Tampa, Florida, USA and a kelp bed: Are populations regulated by settlement or post-settlement processes? Mar Biol 100:485-494

Sano M, Omori M, Taniguchi K, Seki T, Sasaki R (1998) Distribution of the sea urchin Strongylocentrotus nudus in relation to marine algal zonation in the rocky coastal area of the Oshika Peninsula, northern Japan. Benthos Res (Jpn J Benthol) 53:79-87

Sano M, Omori M, Taniguchi K, Seki T (2001) Age distribution of the sea urchin Strongylocentrotus nudus (A. Agassiz) in relation to algal zonation in a rocky coastal area on Oshika Peninsula, northern Japan. Fish Sci 67:628-639

Scheibling RE, Hatcher BG (2007) Ecology of Strongylocentrotus droebachiensis. In: Lawrence JM (ed) Edible sea urchins: biology and ecology, 2nd edn. Elsevier Science Press, Amsterdam, p 353-392

Segawa S (1956) Colored illustrations of the seaweeds of Japan. Hoikusha, Osaka (in Japanese)

Taniguchi K (1996) Primary succession of marine algal communities in the sublittoral zone off Oshika Peninsula, Japan. Nippon Suisan Gakkaishi 62:765-771 (in Japanese with English abstract)

Taniguchi K, Ohkubo H (1975) Sublittoral algal communities in southeast coast of Sado Island, Japan Sea, with special reference to relation between distribution of Sphaerotrichia divaricata and Sargassum spp. and stability of bottom characters. Bull Jpn Sea Natl Fish Res Inst 26: 57-66 (in Japanese with English abstract)

Taniguchi K, Yamada Y (1978) Ecological study on Sargassum patens C. Agardh and S. serratifolium C. Agardh in the sublittoral zone at Iida Bay of Noto Peninsula in the Japan Sea. Bull Jpn Sea Natl Fish Res Inst 29:239-253 (in Japanese with English abstract)

Yoshida T (1998) Marine algae of Japan. Uchida Roukakuho, Tokyo (in Japanese)

Submitted: February 1, 2007; Accepted: June 13, 2007 Proofs received from author(s): November 19, 2007 